\title{
Impact Analysis of the Large-Scale Social Restrictions (PSBB) Policy Implementation in Jakarta
}

\author{
* Hikmahwati, ** Ekasafitri Sangadji, ** Raden Roro Mega Utami \\ * Policy and Health Law Program, Faculty of Public Health Universitas Indonesia \\ ** Health Policy and Administration Department, Faculty of Public Health, Universitas Indonesia
}

Email : hikmahwati.syafri@gmail.com

\begin{abstract}
Jakarta is the province with the highest population density in Indonesia and is also one of the main international gateways to enter Indonesia. These conditions cause a high risk of transmission COVID-19 in Jakarta. One of the government's decisions was applying the Large Scale Social Restrictions (PSBB) policy in Jakarta. This study is a documentation study with Sabatier and Mazmanian's top-down approach that aims to analyze the extent impact of policy implementation, in terms of the policy objectives and community compliance. Compliance analysis uses the results of the Covid-19 Outbreak Survey and Google mobility index. The result shows the compliance of the community in policy implementation. The impact of the PSBB implementation can be seen from the value of the Reproduction number (Rt), which has decreased since the PSBB policy was implemented. Based on those data, it can be concluded that the implementation of the PSBB in Jakarta has been going and implemented well; thus, the consistency from the community and also local government needs to be well maintained.
\end{abstract}

Keywords: COVID-19, Community Compliance, Mobility Index Google, Reproduction Rate

Abstrak. Jakarta merupakan provinsi dengan tingkat kepadatan penduduk tertinggi di Indonesia yang juga sebagai pintu keluar masuknya manusia ke Indonesia. Hal ini menyebabkan resiko penularan COVID-19 di Jakarta menjadi sangat besar. Salah satu kebijakan pemerintah adalah PSBB di DKI Jakarta. Kajian ini merupakan studi dokumentasi dengan pendekatan top-down Sabatier dan Mazmanian yang bertujuan untuk melakukan analisis sejauh mana dampak suatu implementasi kebijakan, ditinjau dari tujuan kebijakan dan kepatuhan masyarakat. Analisis kepatuhan menggunakan hasil Survei Wabah Covid-19 dan indeks mobilitas Google. Hasilnya menunjukkan kepatuhan kelompok sasaran terhadap implementasi kebijakan. Dampak implementasi PSBB dapat terlihat dari nilai Reproduction number (Rt) yang semenjak diberlakukan kebijakan nilainya selalu mengalami penurunan. Berdasarkan keseluruhan data tersebut, maka dapat disimpulkan bahwa implementasi kebijakan PSBB di Jakarta telah berlangsung dan diimplementasikan dengan baik, tinggal menanti konsistensi masyarakat dan pemerintah daerah agar dapat terjaga dengan baik.

Kata Kunci: COVID-19, Kepatuhan Masyarakat, Indeks Mobilitas Google, Angka Penularan

\section{INTRODUCTION}

On March 11, 2020, WHO has stated that the COVID19 is a pandemic that occurs throughout the world. (1) In Indonesia, the public health emergency status was announced on March 31, 2020, through Presidential Decree No. 11 of 2020. (2) On the same day, the government established a policy of Large-Scale Social Restrictions (PSBB) as a form of government intervention to prevent the spread of COVID-19 and was regulated through Government Regulation No. 21 of 2020. (3) The Governor of Jakarta announced that PSBB would be effective from April 10, 2020 (4), and the instructions in implementing PSBB are regulated in DKI Jakarta Governor Regulation No.33 of 2020 (5).

DKI Jakarta is the province with the highest population density in Indonesia(6), which has a population density reaching 16,704 people / $\mathrm{km} 2$ (7). This condition causes a high risk of transmission of COVID-19 in DKI Jakarta. This concern is in line with the results of research conducted by Brosnan (2020) that the risk of infection is estimated to be greater in areas with very high densities in residence, transportation, and work location. (8) This is also consistent with the COVID-19 numbers in Indonesia where DKI Jakarta ranks as the second province with the highest positive confirmation cases of 12,435 people (19.5\%) among 63,749 cases in Indonesia (9)

Every government policy certainly has the risk of failure because of failed or poor implementation. (10) In the end, the evaluation of public policy should be assessed on its impact to the community. (11) This study aims to analyze the impact of policy implementation in terms of policy objectives and community compliance. 


\section{METHODS}

This study uses a descriptive qualitative method by exploring the impact of policy implementation following the expected policy objectives and how community compliance as the target group. Data were collected from documented policies and their progress since they were established until the writing of this study ( \pm three months. We use secondary data from primary material in the form of google mobility index, public health policies, literature and the results of the Covid-19 Outbreak survey conducted by Saiful Munjani Research and Consulting. We also use secondary material, which consists of journal analysis and research results in 2020 since COVID-19.

The COVID-19 Outbreak Survey Data was conducted by Saiful Munjani Research and Consulting using a simple random sampling method from voter populations (Indonesian citizens aged 17 years and over). The survey was conducted in two ways, which are direct interviews on 22-25 March 2020 and a by phone survey on 9-12 April 2020. The survey's margin of error is estimated to be $+/-2.9 \%$, and the confidence level is $95 \%$. (12) The google mobility index shows a change of location and length of stay in different places compared to the baseline. Changes for each day are compared to the baseline for that day of the week, where the baseline value is the median value, over five weeks from January 3 to February 6,2020 . The report shows trends over several weeks with the latest data representing the activity on June 11-13, 2020. (13)

This study uses a top-down model approach by using the "implementation analysis" framework of Sabatier and Mazmanian ideas that focuses on the stages of the policy implementation process.(10) In community compliance analysis, this study uses the PrecedeProceed model, which states that several factors affect community compliance. (14) This factor is presented in a descriptive data presentation to provide an overview of community compliance that leads to the real impact of policy implementation.

\section{RESULTS AND DISSCUSION}

In general, Sabatier and Mazmanian's frameworks explain the variables of the policy implementation process. The variables are divided into two, which are the independent variable and the dependent variable. (10) This dependent variable is the stage of the policy implementation process that consists of: 1) policy output from the implementing agency, 2) the target group compliance, 3) real impacts, 4) perceptions of these impacts, and 5) evaluation of political systems in the form of improvements or efforts to implement improvements. (10)

According to this framework, as described in Wahab
(2012), if the author is only interested in the study of the actual impacts of implementation, that are in line with the policy objectives, it is important to note only the three stages mentioned first. (10) Therefore, this study will focus on policy output points, target group compliance, and the real impact of policies.

\section{Policy Output}

The policy outputs in this study are derived policies or issued policies that have been made after the central government established the PSBB policy as a solution to prevent the spread of COVID-19. The main policy output is Governor Regulation Number 33 of 2020, which regulates the Technical Guidelines for the Implementation of PSBB in DKI Jakarta. Then, there are other policies made to ensure the implementation of the PSBB runs well. These policies can be seen in Table 1.

Table 1. Derived Policies from PSBB Regulation issued by DKI Jakarta Government

\begin{tabular}{|c|c|}
\hline Objectives & Policy \\
\hline $\begin{array}{l}\text { Limit certain activities and movements of } \\
\text { people and/or goods }\end{array}$ & $\begin{array}{l}\text { Keputtusan Kepala Dinas Perhubungan Provinsi DKI Jakarta No. } 71 \\
2020 \text { tentang Petunjuk Teknis Pelaksanaan PSBB bidang } \\
\text { Transportasi } \\
\text { DKI I akarta Provincial Transportation Agency Decree No. } 71 \text { of } \\
2020 \text { regarding Technical Guidelines for the Implementation of } \\
\text { PSBB in Transportation }\end{array}$ \\
\hline $\begin{array}{l}\text { Increase anticipation of spread escalation } \\
\text { of COVID-19 }\end{array}$ & $\begin{array}{l}\text { Peraturan Gubernur Nomor } 41 \text { Tahun } 2020 \text { tentang Pengenaan } \\
\text { Sansis terhadap Pelanggaran PSBB dalam rangka Penanganan } \\
\text { COVID-19 di DKI Jakarata } \\
\text { Governor Regulation No } 41 \text { of } 2020 \text { regarding Imposition of } \\
\text { Sanctions for PSBB Violations in the Term of Handling COVID-19 } \\
\text { in DKI Jakarta }\end{array}$ \\
\hline $\begin{array}{l}\text { Strengthening health management due to } \\
\text { COVID- } 19\end{array}$ & $\begin{array}{l}\text { Keputusan Gubermur Nomor } 494 \text { Tahun } 2020 \text { tentang Perubahan } \\
\text { Atas Keputusan Gubernur Nomor } 378 \text { Tahun } 2020 \text { tentang } \\
\text { Penetapan RS Rujukan Penanggulangan Penyakit COVID-19 } \\
\text { Governor Decree No. } 494 \text { of } 2020 \text { regarding Amendment To } \\
\text { Governor Decree No } 378 \text { of } 2020 \text { regarding The Stipulation of } \\
\text { COVID-19 Referral Hospital }\end{array}$ \\
\hline Overcoming social and economic impacts & $\begin{array}{l}\text { Keputusan Gubermur Nomor } 386 \text { tahun } 2020 \text { tentang Penerima } \\
\text { Bantuan Sosial } \\
\text { Governor Decree No. } 386 \text { of } 2020 \text { regarding Recipients of Social } \\
\text { Funds Support }\end{array}$ \\
\hline
\end{tabular}

\section{Target Group Compliance}

Compliance of target groups is an essential factor that determines the success of policy implementation. Compliance can be seen from the perspective of behavior. (15) According to the Precede-Proceed theory, several factors influence an individual in doing something, one of which is a predisposing factor consisting of knowledge, beliefs, attitudes, values, and norms/culture. (14)

Descriptive data based on Saiful Munjani Research and Consulting survey results show the analysis of community compliance.

Knowledge, Trust, and Attitudes of the Community towards PSBB.

Based on the survey (Graph 1), $89 \%$ of DKI Jakarta citizens know PSBB policy, and 90\% of DKI Jakarta citizens know that DKI Jakarta has implemented PSBB in its area. The results of this survey show that the knowledge, trust, and attitudes of the people of DKI Jakarta lead to a positive direction towards compliance with the implementation of DKI Jakarta's PSBB policy. 
The Precede-Proceed concept also reveals some factors that would strengthen a behavior, one of which is the determination of sanctions for violators. (14) However, based on the survey, it appears that sanctions receive only little support from the citizen.

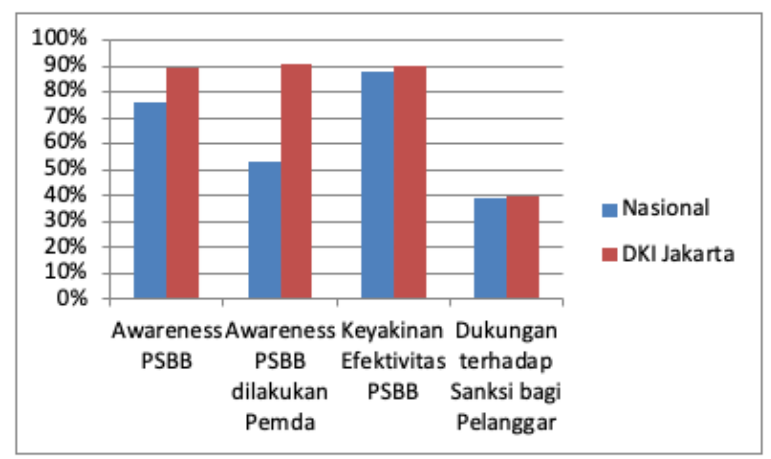

Figure 1. Overview of Knowledge, Trust and Attitudes towards the Imposition of Sanctions for PSBB Violators between all Indonesian and the DKI Jakarta Community in particular (12)

How Community Support the Values in PSBB.

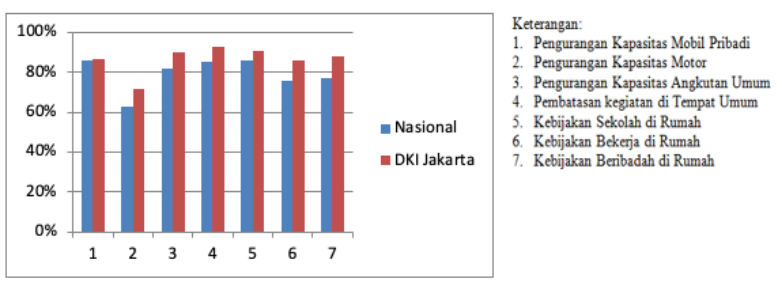

Figure 2. Overview of compliance toward PSBB regulation in all Indonesians and the DKI Jakarta citizen in particular (12)

Based on the survey results, DKI Jakarta citizen support on limiting outdoor activities is quite high. (12) Their support tends to be higher than the national support rate. This result may be due to the influence of environmental factors or supporting factors in a behavioral change. (14) The people of DKI Jakarta certainly know a higher risk of exposing themselves to the environment, as it is known that an environment with high population density will have a higher risk of transmission of infectious diseases. It can be assumed that if the population has a positive view on a policy, it will produce positive support that influences the success of policy implementation. (15)

The SMRC survey results are then compared with the search results from google mobility index (Figure 3). The data shows that the implementation of PSBB in Jakarta is more obeyed than the national level PSBB implementation data. The highest reduction of movement was found in community visits to the park, which was $91 \%$. The policy on the temporary closure of park and city forest facilities was issued before the PSBB decision by the central government, which was March 13, 2020. The increasing number of people who stay at home from its baseline by $14 \%$ showed community compliance with the policies imposed by the government.

\section{The Real Impact of The Policy}

The primary purpose of PSBB is to prevent the possible spread of the SARS-COV-2 virus. (5) Therefore, if we want to see the real impact of the PSBB, one of them can be seen from the decrease in the Reproduction number (Rt) value. Reproduction Number (Rt) indicates the level of transmission (16) If $R$ is equal to 4 (four), it means that one person has the potential to transmit to four people. If $\mathrm{R}$ is less than 1 (one), it means that the potential to transmit to others is almost non-existent (16). Data from the University of Indonesia's Faculty of Public Health team in the Governor's presentation at the June 4, 2020 press conference showed that in the period before the PSBB, the estimated value of $\mathrm{Rt}$ was close to 4 , then after PSBB the value of Rt decreased to 1.03 , and at the end of the mass PSBB was 0.99. (16)

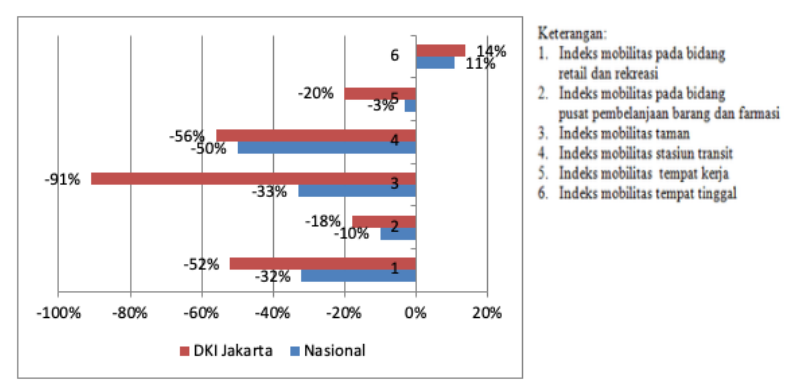

Figure 3. Comparison of Google's Mobility Index between National and DKI Jakarta (13)

\section{CONCLUSIONS}

In the stages or process of policy implementation, it begins with the translation of policy objectives in the form of derived policies. The aim of implementing the PSBB is to prevent the spread of COVID-19. This goal is then translated and implemented by the government agency, in this case, the DKI Jakarta government, through Pergub No. 33 of 2020 and its derived policies. Then the implementation success is determined by the community's compliance with PSBB regulation. Community compliance can be seen from its knowledge, attitudes, support, and behavior toward the implementation of the PSBB. Based on the results of the SMRC survey and the google mobility index, it appears that the Jakarta community's compliance with the implementation of the PSBB is quite good. Then, to see the real impact of PSBB policy implementation, one of which is the decrease in the spread of COVID19. One of the parameters that can be used is the Reproduction number (Rt) in DKI Jakarta, which has continued to decline since the implementation of the PSBB. This result proves the successful implementation of PSBB in DKI Jakarta. 


\section{RECOMMENDATION}

Giving reward as an appreciation from the government to the community after the implementation of the PSBB policy, for example, in the form of tax exemption for workplaces that can implement the PSBB rules for three terms. Rewarding is expected to make people feel special and want to continue implementing health protocols even though DKI Jakarta no longer applies the PSBB policy.

Providing resources for the target group. PSBB certainly has an impact not only on people's behavior but also on the economy and the psychological condition of the community. The government, as the policy provider, is expected to be able to facilitate people's needs that affected by COVID-19. These resources can be by providing new jobs for affected communities or adequate health facilities.

After the success of PSBB, there should be changes in community behavior, such as creating discipline habits, in compliance with the health protocol, even though DKI Jakarta no longer applies the PSBB. Discipline to adhere to health protocols should be done while the COVID-19 pandemic is still ongoing.

\section{REFERENCES}

1. WHO. WHO Director-General's opening remarks at the media briefing on COVID-19 11 March 2020 [Internet]. 2020 [dikutip 13 April 2020]. Tersedia pada: https://www.who.int/dg/speeches/detail/whodirector-general-s-opening-remarks-at-themedia-briefing-on-covid-19---11-march-2020

2. Kementerian Sekretariat Negara. Keputusan Presiden Nomor 11 Tahun 2020. 2020.

3. Kementerian Hukum dan HAM. Peraturan Pemerintah Nomor 21 Tahun 2020. 2019;(022597):22597-600.

4. Hamalatul Qur'ani. 4 Diktum Keputusan Menkes tentang PSBB di Jakarta hukumonline.com [Internet]. 2020 [dikutip 29 April 2020]. Tersedia pada: https://www.hukumonline.com/berita/baca/lt5e 8ca22c1aa42/4-diktum-keputusan-menkestentang-psbb-di-jakarta?page $=1$

5. Gubernur DKI Jakarta. Peraturan Gubernur Nomor 33 Tahun 2020. CoronaJakartaGoId [Internet]. 2020;7:583-606. Tersedia pada: https://corona.jakarta.go.id/storage/documents/ peraturan-gubernur-nomor-33-tahun-2020tentang-pelaksanaan-psbb-dalam-penanganancovid-19-di-provinsi-dki-jakarta5e987d4687853.pdf
6. Badan Pusat Statistik. Kepadatan Penduduk menurut Provinsi, 2000-2015 [Internet]. 2015 [dikutip 14 Juni 2020]. Tersedia pada: https://www.bps.go.id/dynamictable/2015/09/0 7/842/kepadatan-penduduk-menurut-provinsi2000-2015.html

7. Badan Pusat Statistik DKI Jakarta. BERAPA KEPADATAN PENDUDUK DKI JAKARTA SAAT INI? - Unit Pengelola Statistik [Internet]. 2020 [dikutip 14 Juni 2020]. Tersedia pada: http://statistik.jakarta.go.id/berapa-kepadatanpenduduk-dki-jakarta-saat-ini/

8. Brosnan D. Early observations on the pandemic and population density. CE Think Tank Newswire [Internet]. 2020; Tersedia pada:

https://search.proquest.com/docview/23900976 03 ? accountid $=17242$

9. Kementerian Kesehatan. Peta Sebaran | Gugus Tugas Percepatan Penanganan COVID-19 [Internet]. Data Covid-19. 2020 [dikutip 6 Juli 2020]. Tersedia pada: https://covid19.go.id/peta-sebaran

10. Wahab SA. Analisis Kebijakan: Dari Formulasi ke Penyusunan odel-Model Implementasi Kebijakan Publik. Jakarta: Bumi Aksara; 2012.

11. Muchsin dan Fadillah Putra. Hukum dan Kebijakan Publik. Surabaya: Averroes Press dan Universitas Sunan Giri; 2002.

12. Saiful Mujani Research and Consulting. Wabah COVID-19: Sikap Atas Kebijakan dan Kondisi Ekonomi [Internet]. 2020 [dikutip 16 Juni 2020]. Tersedia pada: https://drive.google.com/file/d/1nmRpSMhRtJ C-ZfHBFysHtfK928_DA73M/view

13. Google. Mobility Changes Indonesia (June 7, 2020) [Internet]. google.com/covid19/mobility. 2020 [dikutip 15 Juni 2020]. Tersedia pada: https://www.gstatic.com/covid19/mobility/202 0-06-07_ID_Mobility_Report_en.pdf

14. Liza Cragg WN. Health Promotion Practice Second edition. England: Open University Press; 2015.

15. Akib H. IMPLEMENTASI KEBIJAKAN: Apa, Mengapa, dan Bagaimana. J Adm Publik,. 2010;1(1).

16. Paparan Gubernur DKI Jakarta. Indikator Pelonggaran Pembatasan Sosial. 2020; 